\title{
VARIABILITY OF PHYTOPLANKTON COMMUNITIES IN CENTRAL EAST ATLANTIC (ESTOC)
}

\author{
D. Vega-Moreno* ${ }^{1}$, C. Llerandi-García ${ }^{1}$, A. Cianca ${ }^{1}$, \\ L. Cardona ${ }^{1}$, M. Villagarcía ${ }^{1}$, R. Santana, M.J. Rueda ${ }^{1}$, \\ O. Llinás ${ }^{2}$.
}

Abstract-Phytoplankton pigment composition has been studied during two years at station located in the subtropical North Atlantic Ocean, in a station for time series in the ocean. The concentration and proportion of several diagnostic pigments is used for the determination of phytoplankton communities present in the area, and consequently their seasonal and temporal variability. The knowledge of phytoplankton composition in large temporal series is crucial for a better understanding of biogeochemical cycles and for the improvement of the existent chlorophyll data on the series.

Keywords: phytoplankton, biomarker pigments, time series, HPLC, size group, distribution.

\section{INTRODUCTION}

The European Station for Time Series in the Ocean (ESTOC) is operated since 1994. It is located about $100 \mathrm{~km}$ North of Gran Canaria Island ( $\left.29^{\circ} 10^{\prime} \mathrm{N}, 15^{\circ} 30^{\prime} \mathrm{W}\right)$, East of the North Atlantic subtropical gyre [1], in an area of deep oligotrophic waters (Fig. 1). This station is currently operated by the Canary Institute of Marine Science (ICCM) and it is also involved in the European Deep Observatories Network (EuroSITES).

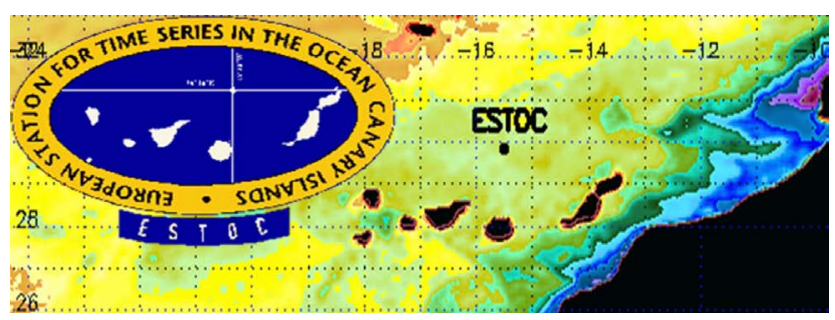

Fig 1. ESTOC situation

Marine phytoplankton plays an important role in the carbon withdrawal from the atmosphere, in the primary production and in the biogeochemical fluxes [2]; however, the variability in phytoplankton population composition modulates the influence in the functioning of the pelagic ecosystem and in marine biogeochemical cycles [3].

Distribution and succession of phytoplankton in the ocean is the result of the adaptation of microalgal groups to
1) Oceanography Department. Canary Institute of Marine Science (ICCM).

2) PLOCAN. Oceanic Platform of the Canary Islands. Telde, Canary Islands, Spain.

*email: daura@iccm.rcanaria.es

environmental conditions (temperature, nutrients, light field, turbulence, etc.) [4].

Changes in the phytoplankton community structure or composition [5], or changes in their physiological state [6] can be characterized by specific biomarker pigments or by particular pigment ratios [7].

Sieburth et al. [8] grouped the phytoplankton cell size in three main categories: microphytoplankton (20-200 $\mu \mathrm{m}$ ESD, Equivalent Spherical Diameter), nanophytoplankton (2-20 $\mu \mathrm{m}$ ESD) and picophytoplankton (0,2-2 $\mu \mathrm{m}$ ESD). Using this classification as reference, Vidussi et al. [9] proposed a method to distribute phytoplankton populations in the Siebuth et al. categories according to their HPLC-pigment signatures.

Phytoplankton cell size and Phytoplankton Functional Types (PFT) distributions were found to be highly influenced by the physical and chemical characteristics of the environments. It can be evaluated with the abundance of photosynthetic pigments, especially photosynthetic carotenoids (PSCs) and photoprotective carotenoids (PPCs). The proportion of carotenoid pigments is used for the determination of phytoplankton groups which are present following the equations developed by Vidussi et al. [9].

Phytoplankton Functional Groups (PFG) derived from diagnostic pigments and optical indices, are analyzed and interpreted in relation to regional hydrodynamics, so as to increase our knowledge about the complex biological patterns existing in ESTOC during the studied period.

\section{Methodology}

\section{A. Sampling and Pigment Analysis}

In ESTOC the phytoplankton pigments analysis by HPLC has been introduced recently as part of the in situ sampling program, complementing chlorophyll a data available since 1994. Since the winter of 2008 the variation of phytoplankton composition has been studied, with a periodicity at least of one sampling per season. Phytoplankton composition has been studied in different months covering from December 2008 to May 2009.

Pigments were extracted in $100 \%$ methanol with the use of ultrasonication and clarified by centrifugation. They were 
analysed by reverse phase HPLC procedure [10] using a Waters Spherisorb $5 \mu \mathrm{m}$ ODS2 4.6x250 mm C18 column. Pigments were detected at $436 \mathrm{~nm}$ (excitation) and $680 \mathrm{~nm}$ (emission) with a fluorometer detector and at $445 \mathrm{~nm}$ with a PDA detector. Chlorophyll a (Chla) and chlorophyll b (Chlb) standards were obtained from Sigma-Aldrich Ltd., and other pigment standards were purchased from the DHI Institute for Water and Environment (Denmark). The method used for the analysis does not separate divinyl and monovinyl chlorophyll a, nor divinyl and monovinyl chlorophyll $b$. Limits of detection were $0.001 \mu \mathrm{g} \mathrm{L}^{-1}$.

\section{B. Pigment Indices}

Photo-pigment indices were derived to assess the changing contribution of chlorophylls and carotenoids to the total pigment pool [5]. The carotenoid pigments were discriminated as photosynthetic carotenoids (PSC) and photoprotective carotenoids (PPC). The photopigment indices symbolised as TChla, PSCs, PPCs, DPs (Diagnostic Pigments) and PI (Photoprotection Index) are described in Table 1.

Table 1. The symbols, names, formulae and selected taxonomic designations [11] for chlorophylls, carotenoids, pigment sums and pigment indices

\begin{tabular}{|c|c|c|}
\hline $\begin{array}{c}A b b \\
v .\end{array}$ & Pigment & Designation \\
\hline Chla & Chlorophyll a & \\
\hline Chlb & Chlorophyll b & Chlorophytes \\
\hline Allo & Alloxanthin & Cryptophytes \\
\hline But & 19'-Butanoyloxyfucoxanthin & Haptophytes (major) \\
\hline Caro & Carotenes & $\alpha$-plus $\beta$-carotenes \\
\hline Diad & Diadinoxanthin & \\
\hline Diato & Diatoxanthin & \\
\hline Fuco & Fucoxanthin & Diatoms (major) \\
\hline Hex & $19^{\prime}-$ & Haptophytes \\
\hline $\begin{array}{l}\text { Peri } \\
\text { Zea }\end{array}$ & $\begin{array}{c}\text { Hexanoyloxyfucoxanthin } \\
\text { Peridinin } \\
\text { Zeaxanthin }\end{array}$ & $\begin{array}{l}\text { Dinoflagellates } \\
\text { Cyanophytes \& } \\
\text { Prochlorophytes } \\
\end{array}$ \\
\hline $\begin{array}{c}\text { TChl } \\
\text { a }\end{array}$ & Total Chlorophyll a & Chla + divinyl Chla \\
\hline PPC & Photoprotective Carotenoids & $\begin{array}{c}\text { Allo }+ \text { Diad }+ \text { Diato }+ \text { Zea }+ \\
\text { Caro }\end{array}$ \\
\hline PSC & Photosynthetic Carotenoids & But + Fuco + Hex + Peri \\
\hline DP & Total Diagnostic Pigments & $\mathrm{PSC}+\mathrm{Allo}+\mathrm{Zea}+\mathrm{Chlb}$ \\
\hline PI & Photoprotection Index & $($ Diad + Diato + Zea $) /$ Chla \\
\hline $\mathrm{mPF}$ & $\begin{array}{l}\text { Microphytoplankton } \\
\text { Proportion }\end{array}$ & $($ Fuco + Peri $) / D P$ \\
\hline $\mathrm{nPF}$ & $\begin{array}{c}\text { Nanophytoplankton } \\
\text { Proportion }\end{array}$ & $(\mathrm{Hex}+\mathrm{But}+$ Allo $) / \mathrm{DP}$ \\
\hline $\mathrm{pPF}$ & $\begin{array}{l}\text { Picophytoplankton } \\
\text { Proportion }\end{array}$ & $(\mathrm{Zea}+\mathrm{Chlb}) / \mathrm{DP}$ \\
\hline
\end{tabular}

Phytoplankton size classes, symbolised as $\mathrm{mPF}$ (microphytoplankton), nPF (nanophytoplankton) and $\mathrm{pPF}$ (picophytoplankton) (Table 1), were derived from diagnostic pigment indices (DP) [9] to be used as a cell size functional grouping of the phytoplankton natural populations. The diagnostic indices used in this study are not definitive for phytoplankton classification as has been previously shown by Barlow et al. [5], but they are useful for indicating the major groups which contribute to the phytoplankton community.

\section{RESULTS}

Diagnostic pigments used to estimate the relative abundances of different phytoplankton groups are considered independent to each other because they are biomarkers for each phytoplankton group [12]. Vertical profiles of the most relevant diagnostic pigments are showed in Fig. 2
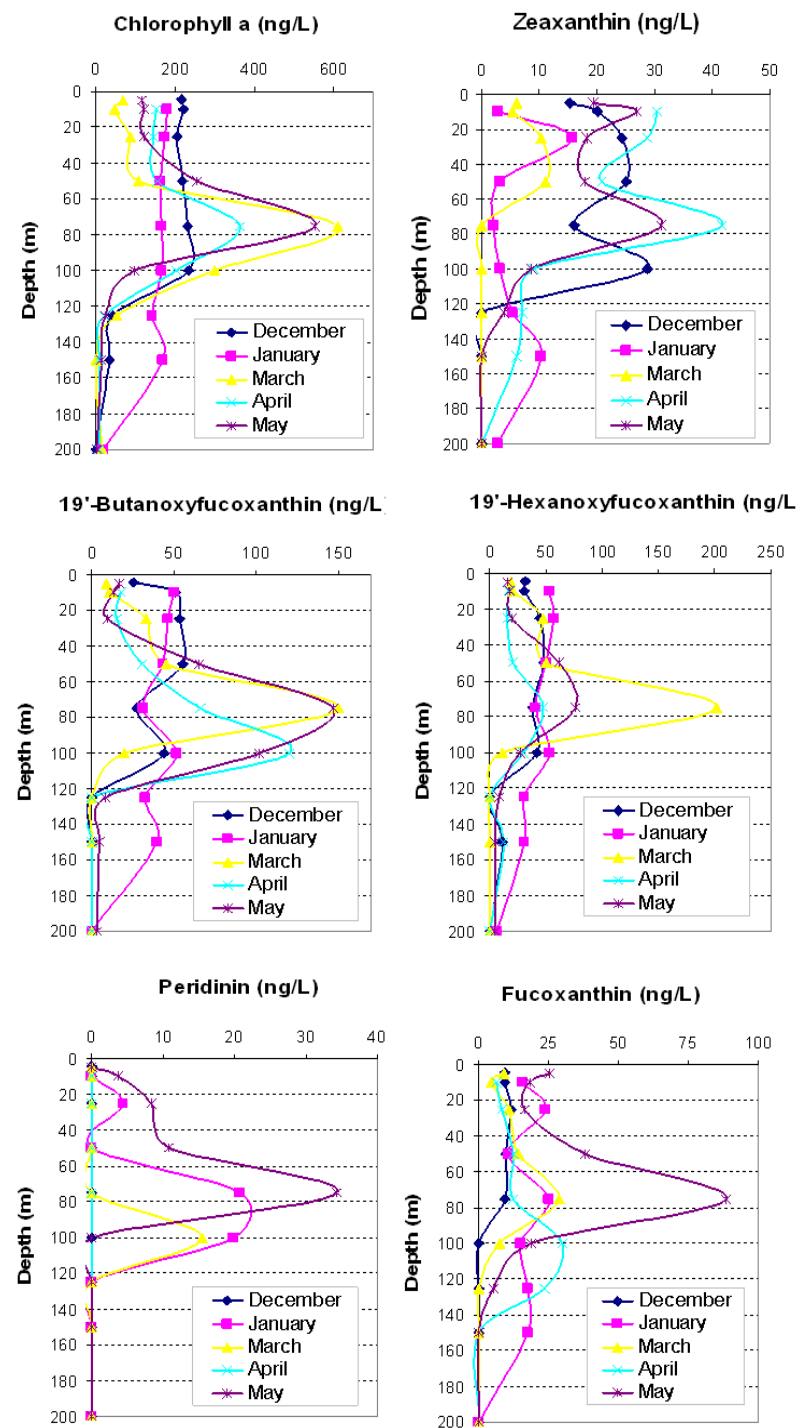

Fig 2. Vertical distribution of phytoplankton pigment in ESTOC between December 2008 and May 2009 
The PPC (photoprotective carotenoids), PSC (photosynthetic carotenoids) and DP (total diagnostic pigments) indexes provide an estimation of the physiological condition of the phytoplankton community as a result of the environmental and trophic conditions.

From this figure it can be observed that between December 2008 and May 2009 it is observed two maximums of concentration, in March (early spring) and May (late spring) and one sub-maximum in April, all of them at 75 meters of depth approximately.

The abundance of each pigment is different and also varies in the different months studied. The most abundant pigments, aside from Chlorophyll a that is present every phytoplankton group, are: fucoxanthin, 19'butanoyoxyfucoxanthin and 19'-hexanoyoxyfucoxanthin.

According the pigment concentration it can be studied phytoplankton group composition following the relations give in Table 1.

The distribution of the different kind of pigments and consequently, the phytoplankton group which it belongs, vary between the different months, with a predominance of nanophytoplankton

- December: predominance of Zeaxanthin (pPF) and 19'-Butano. (npF).

- January: high vertical mixture, predominance of 19'-Butano., 19'-Hexano. (nPF) and Fucoxanthin (Diatoms, $\mathrm{mPF}$ ), presence of Peridinin (Dinoflagellates).

- March: Maximum of Chlorophyll a, mainly due to the presence of haptophytas (19'-Hexano.) and other types of nPF (19'-Butano).

- April: high concentration of zeaxanthin (pPF) and 19'-Butano. (nPF).

- May: Maximum Chlorophyll a, but due to high values of 19'- Butano. (nPF), Fucoxanthin (Diatoms and others) and Peridinin (Dinoflagellates), both from the microphytoplankton group.

The PPC (photoprotective carotenoids), PSC (photosynthetic carotenoids) and DP (total diagnostic pigments) indexes provide an estimation of the physiological condition of the phytoplankton community as a result of the environmental and trophic conditions.

The approach taken by Vidussi et al. [9] was applied by Hooker et al. [13] within the international HPLC Analysis Round-Robin Experiment (SeaHARRE-2). Following this procedure, it was determined the percentage of each phytoplankton group (microphytoplankton, nanophytoplankton and picophytoplankton) in the different months sampled. In Figure 3 it is showed, during the studied period of time, the variability in the founded amount of each group.
ESTOC December 2008

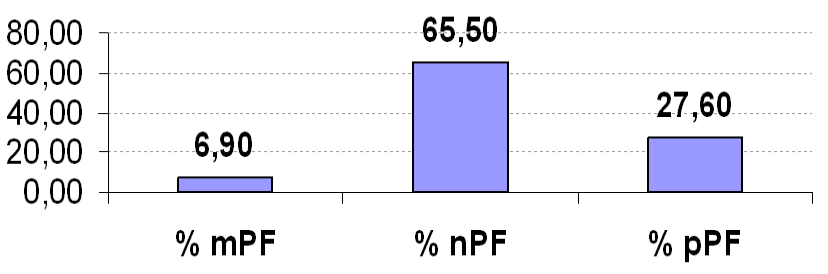

ESTOC January 2009

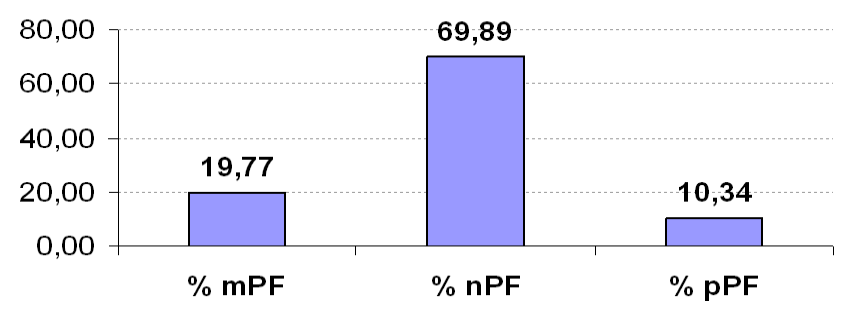

ESTOC March 2009

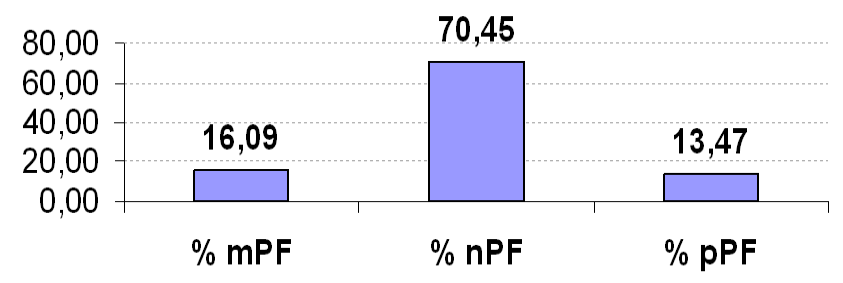

ESTOC April 2009

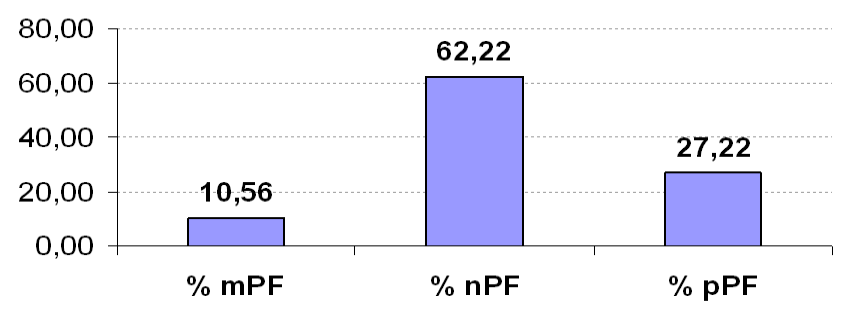

ESTOC May 2009

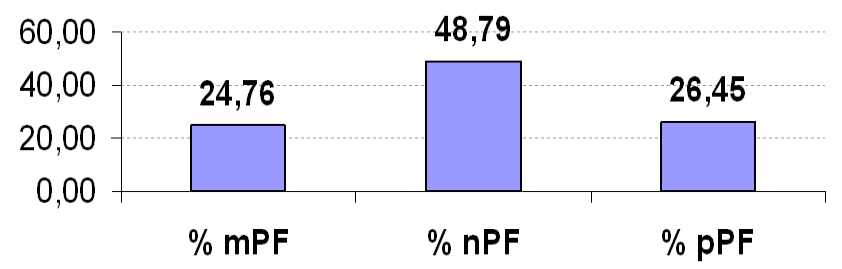

Fig 3. Phytoplankton classification by sizes according to the relations give in Table 1 [9] 


\section{CONCLUSIONS}

According to these results it can be observed the high variability between the different phytoplankton pigments even if the chlorophyll a maximum was similar (such as in March and May), changing the proportion of each phytoplankton group in the water column. Until 2008 it was only possible to study the variability in chlorophyll a concentration, and consequently, the variability on total phytoplankton abundance. From 2008 it is also possible in ESTOC to study the variability in phytoplankton composition, the predominant groups and communities in each station and in the next years, to study the interannual variability.

This variability in the composition of the phytoplankton communities in the water column will change the biogeochemical cycle in ESTOC, modifying chemical and biological parameters that are measured also in this station. For that reason it is important this implementation at ESTOC and other stations.

\section{ACKNOWLEDGMENT}

This work is support by the Canary Institute of Marine Science and the Oceanic Platform of the Canary Islands, PLOCAN.

\section{REFERENCES}

[1] Neuer, S.; Cianca, A.; Helmke, P.; Freudenthal, T.; Davenport, R.; Meggers, H.; Knoll, M.; Santana-Casiano, J. M.; González-Dávila, M.; Rueda, M.-J. \& Llinás, O. Biogeochemistry and hydrography in the eastern subtropical North Atlantic gyre. Results from the European time-series station ESTOC. Progress in Oceanography, 2007, 72, 1-29

[2] Legendre, L. \& Rassoulzadegan, F., 1996. Food-web mediated export of biogenic carbon in oceans: hydrodynamic control. Marine Ecology Progress Series, 145, 179-193

[3] Nair, A., Sathyendranath, S., Platt, T., Morales, J., Stuart, V., Forget, M.H., Devred, E., Bouman, H., 2008. Remote sensing of phytoplankton functional types. Remote Sensing of Environment 112, 3366-3375.

[4] Margalef, R., 1978. Life forms of phytoplankton as survival alternatives in an unstable environment. Oceanologica Acta, 1(4), 493-509.

[5] Barlow, R., Stuart, V., Lutz, V., Sessions, H., Sathyendranath, S., Platt, T., Kyewalyanga, M., Clementson, L., Fukasawa, M., Watanabe, S., Devred, E., 2007. Seasonal pigment patterns of surface phytoplankton in the subtropical southern hemisphere. Deep-Sea Research I 54, 1687-1703.

[6] Trees, C.C., Clark, D.K., Bidigare, R.R., Ondrusek, M.E., Mueller, J.L., 2000. Accessory pigments versus chlorophyll a concentrations within the euphotic zone: a ubiquitous relationship. Limnology and Oceanography $45,1130-1143$.

[7] Aiken, J., Pradhan, Y., Barlow, R., Lavender, S., Poulton, A., Holligan, P., Hardman-Mountford, N., 2009. Phytoplankton pigments and functional types in the Atlantic Ocean: A decadal assessment, 1995-2005. Deep-Sea Research II, 56, 899-917.

[8] Sieburth, J. M., Smetacek, V., Lenz, J., 1978. Pelagic ecosystem structure: Heterotrophic compartments of the plankton and their relationship to plankton size fractions. Limnology and Oceanography, $23,1256-1263$

[9] Vidussi, F., Claustre, H., Manca, B., Luchetta, A. Marty, J., 2001. Phytoplankton pigment distribution in relation to upper thermocline circulation in the eastern Mediterranean Sea during winter. Journal of Geophysical Research 106, 19939-19956.

[10] Wright, S., Jeffrey, S., Mantoura, R., Llewellyn, C., Bjornland, T., Repeta, D., Welschmeyer, N., 1991. Improved HPLC method for the analysis of chlorophylls and carotenoids from marine phytoplankton. Marine Ecology Progress Series 77, 183-196.

[11] Jeffrey, S., Mantoura, R., Wright S., (ed.), 2005. Phytoplankton Pigments in Oceanography. Guidelines to Modern Methods, UNESCO.

[12] Wright, S., Van den Enden, R., 2000. Phytoplankton community structure and stocks in the East Antartic marginal ice zone (BROKE survey, January-March 1996) determined by CHEMTAX analysis of HPLC pigment signatures. Deep-Sea Research II 47, 2363-2400.

[13] Hooker, S.; Heukelem, L.; Thomas, C.; Claustre, H.; Ras, J.; Barlow, R.; Sessions, H.; Schlüter, L.; Perl, J.; Trees, C.; Suart, V.; Head, E.; Clemenston, L.; Fishwick, J.; Llewellyn, C. \& Aiken, J. The Second SeaWIFS HPLC Analysis Round-Robin Experiment (SeaHARRE-2) NASA/TM-2005-212785, August 2005 